\title{
TOKO MILIK RAKYAT (TOMIRA) DAN KESEJAHTERAAN MASYARAKAT KULON PROGO
}

\section{TOKO MILIK RAKYAT (TOMIRA) AND THE COMMUNITY WELFARE OF KULON PROGO}

\author{
Azka Abdi Amrurobbi1, Moch Edward Trias Pahlevi² \\ ${ }^{1}$ Magister Politik Pemerintahan Universitas Gadjah Mada \\ 2Magister Ilmu Pemerintahan Universitas Muhammadiyah Yogyakarta \\ E-mail: azkaabdi@mail.ugm.ac.id
}

\begin{abstract}
Toko Milik Rakyat (Tomira) is a government policy based on Kulon Progo Regional Regulation No. 11 of 2011 concerning Protection and Empowerment of Traditional Markets and the Arrangement of Modern Shopping Centers and Stores. Tomira is in the form of a partnership between Micro, Small and Medium Enterprises (MSMEs) with modern stores such as Alfamart and Indomaret in Kulon Progo. The purpose of the Tomira's policy is to improve the welfare of the community and increase economic growth. The question to be answered in this research is related to the process of forming a Tomira's policy. This study uses an analysis for policy approach with a focus on analyzing the policy process using a society based governance model. The method in this research uses the literature study method which is collaborated with qualitative methods. The results of this resarch explain that in the process of policy formulation through improving the welfare of the Tomira, the government should be oriented to the society in order to create the widest prosperity for the society. Conflicts of interest between the actors allowed to appear in the policy. Behind that, there is also a political side to the policy. The welfare improvement policy through the Tomira was used by the regional head of Kulon Progo Regency as a political strategy to increase his electability. The author considers that there needs to be regulations that clarify the technical aspects of improving welfare through Tomira.
\end{abstract}

Keywords: Toko Milik Rakyat (Tomira), Community Welfare, Policy Analysis

\begin{abstract}
ABSTRAK
Toko Milik Rakyat (Tomira) merupakan sebuah kebijakan pemerintah yang dilandasi oleh Peraturan Daerah Kulon Progo No. 11 tahun 2011 tentang Perlindungan dan Pemberdayaan Pasar Tradisional Serta Penataan Pusat Perbelanjaan dan Toko Modern. Tomira tersebut berbentuk kemitraan antara Usaha Mikro Kecil dan Menengah (UMKM) dengan toko modern seperti Alfamart dan Indomaret di Kulon Progo. Tujuan dari kebijakan Toko Milik Rakyat (Tomira) ini yaitu untuk meningkatkan kesejahteraan masyarakat dan meningkatkan pertumbuhan ekonomi. Pertanyaan yang hendak dijawab dalam penelitian ini terkait dengan proses pembentukan kebijakan Toko Milik Rakyat (Tomira). Penelitian ini menggunakan pendekatan analisis untuk kebijakan (analysis for policy) dengan fokus pada analisis proses kebijakan dengan menggunakan model society based governance. Metode dalam penelitian ini menggunakan metode studi kepustakaan yang dikolaborasikan dengan metode kualitatif. Hasil dari penelitian ini menjelaskan bahwa dalam proses pembentukan
\end{abstract}

Journal of Governance and Local Politics (JGLP)

ISSN (online): 2684-9992, Volume: 2, Nomor: 1, Mei 2020

Page 48 
kebijakan peningkatan kesejahteraan melalui Toko Milik Rakyat (Tomira), pemerintah harus berorientasi kepada masyarakat dengan tujuan agar dapat menciptakan kesejahteraan yang seluas-luasnya bagi masyarakat. Konflik kepentingan antar aktor memungkinkan untuk muncul dalam kebijakan tersebut. Dibalik itu juga terdapat sisi politis dalam kebijakan tersebut. Kebijakan peningkatan kesejahteraan melalui Toko Milik Rakyat (Tomira) digunakan oleh kepala daerah Kabupaten Kulon Progo sebagai strategi politik untuk meningkatkan elektabilitasnya. Penulis menganggap bahwa perlu ada peraturan yang memperjelas terkait teknis kebijakan peningkatan kesejahteraan melalui Toko Milik Rakyat (Tomira).

Kata kunci: Toko Milik Rakyat (Tomira), Kesejahteraan Masyarakat, Analisis Kebijakan

\section{PENDAHULUAN}

Berjamurnya toko modern berjejaring seperti Alfamart dan Indomaret akhir-akhir ini mengakibatkan persaingan pasar semakin panas. Walaupun pendirian toko modern sudah diatur baik dalam peraturan pemerintah pusat seperti Peraturan Presiden No. 112 tahun 2007 tentang Penataan dan Pembinaan Pasar Tradisional Pusat Perbelanjaan dan Toko Modern maupun pemerintah daerah seperti contohnya Peraturan Daerah (Perda) Kabupaten Kulonprogo No 11 tahun 2011 tentang Perlindungan dan Pemberdayaan Pasar Tradisional Serta Penataan Pusat Perbelanjaan dan Toko Modern namun jumlah toko modern seperti Alfamart dan Indomaret kian hari kian bertambah. Berdasarkan data yang dirilis oleh Kementerian Perdagangan (Kemendag) Republik Indonesia (2014) melalui Direktur Jenderal Perdagangan dalam Negeri menjelaskan bahwa jumlah pasar modern yang ada di seluruh Indonesia pada tahun 2014 saja mencapai 23.000 unit. Jumlah tersebut menunjukan bahwa adanya peningkatan sebesar 14\% dalam tiga tahun terakhir. Dengan komposisi 14.000 unit lebih merupakan kelompok usaha minimarket, dan sisanya adalah supermarket.

Keberadaan usaha toko modern tidak terlepas dari analisis kondisi ekonomi dan sosial dari masyarakat. Maka dari itu, kehadiran toko modern diharapkan mampu untuk dapat bersinergi dengan Usaha Mikro Kecil dan Menengah (UMKM) yaitu dengan cara bermitra serta memberikan pembinaan dan bimbingan terkait sifat saling memerlukan, saling memperkuat, dan saling menguntungkan untuk menciptakan ekonomi kerakyatan. 
Ekonomi Kerakyatan adalah sebuah sistem ekonomi dimana masyarakat diikutsertakan kedalam proses pembangunan. Menurut Zulkarnain (2006) ekonomi kerakyatan adalah sebuah sistem ekonomi yang harus dianur sesuai dengan falsafah negara Indonesia yang menyangkut aspek yakni keadilan, demokrasi ekonomi, dan keberpihakan kepada ekonomi rakyat. Selain itu, sistem ekonomi kerakyatan sesuai dengan UUD 1945 adalah sistem ekonomi yang demokratis, yang artinya bahwa pencapaian kesejahteraan dalam masyarakat dilakukan dengan cara yang demokratis (Yasa, 2008). Tujuan utama dari pengembangan ekonomi kerakyatan adalah kesejahteraan rakyat yang dapat terwujud apabila pembangunan mengarah kepada perubahan struktur dalam masyarakat. Perubahan struktur diawali melalui proses peningkatan produksi dan distribusi yang kemudian dapat membuka kesempatan kerja.

Usaha Mikro Kecil dan Menengah (UMKM) adalah unit usaha produktif yang berdiri sendiri, dilakukan oleh perorangan atau badan usaha di semua sektor ekonomi (Tambunan, 2010). Melalui Usaha Mikro Kecil dan Menengah (UMKM) diharapkan mampu untuk menjadi stabilisator dan dapat mengangkat kesejahteraan masyarakat dengan cara ikut serta dalam mengelola pasar. Salah satu cara yang dapat dilakukan untuk meningkatkan kesejahteraan masyarakat yaitu melalui kemitraan yang dilakukan antara UMKM dan toko modern.

Toko Milik Rakyat (Tomira) merupakan salah satu kebijakan Pemerintah Daerah Kabupaten Kulon Progo yang berbentuk kemintraan antara Usaha Mikro Kecil dan Menengah (UMKM) dengan toko modern seperti Alfamart dan Indomaret yang dilandasi oleh Peraturan Daerah Kabupaten Kulon Progo No. 11 tahun 2011 tentang Perlindungan dan Pemberdayaan Pasar Tradisional serta Penataan Pusat Perbelanjaan dan Toko Modern. Kebijakan terkait dengan Toko Milik Rakyat (Tomira) yang dicanangkan oleh Pemerintah Kabupaten Kulonprogo, secara otomatis Usaha Mikro Kecil dan Menengah (UMKM) lokal Kabupaten Kulonprogo akan terus meningkatkan pelayanan dan mengutamakan kualitas produknya sehingga ada kontestasi secara sehat yang terus terjaga dalam perkembangan usaha. Selain itu, tuntutan peningkatan kualitas dan kuantitas produk untuk bisa menjadi tuan rumah di masyarakat. Hal ini bertujuan agar masyarakat dalam hal ini masyarakat Kulonprogo akan tetap memilih produk lokal meskipun banyak produk yang mirip di pasaran. Selain itu, pemenuhan tingkat ketersediaan produk juga akan sangat penting untuk 
melayani permintaan yang sangat tinggi. Penulis berargumen bahwa kebijakan terkait peningkatan kesejahteraan melalui Toko Milik Rakyat (Tomira) dirasa memiliki beberapa masalah yang salah satunya disebabkan oleh dilema yang terjadi di pemerintah terkait orientasi atau keberpihakan kebijakan.

Studi yang membahas terkait dengan kebijakan Toko Milik Rakyat (Tomira) dapat ditemukan dalam berbagai literatur yang sudah ada. Dalam penelitian yang dilakukan oleh Harto (2017) bertujuan untuk mengetahui makna sosial dari kebijakan Tomira. Penelitian tersebut menunjukan bahwa kebijakan Toko Milik Rakyat (Tomira) disikapi positif oleh koperasi dan pelaku Usaha Mikro, Kecil, dan Menengah (UMKM). Produk lokal yang minimal sudah memiliki izin Produksi Pangan - Industri Rumah Tangga (PP-IRT) dapat dipasarkan di Tomira. Selain itu kerjasama antara pemilik Tomira memudahkan pendistribusian produk lokal. Sedangkan Safitri (2017) dalam penelitiannya yang berjudul tinjauan etika bisnis islam terhadap praktik Tomira menunjukan bahwa pelaksanaan kebijakan Tomira dapat mengurangi toko modern berjejaring yaitu 18 toko yang melanggar perda menjadi 11 toko. Selain itu perusahaan belum memenuhi tanggung jawab keadilan yang proporsional yaitu 50\%-50\%. Pengelolaan manajemen dan pemasok barang utama masih dikendalikan oleh perusahaan. Susilo dan Rijanta (2017) juga menjelaskan bahwa Tomira merupakan salah satu produk dari program pemerintah Kulon Progo yaitu Bela-Beli Kulon Progo. Walaupun bukan menjadi produk yang paling unggul. Hasil penelitian terbaru yang dilakukan oleh Setiyawati (2019) juga menunjukan bahwa adanya Perda Kabupaten Kulon Progo No. 11 tahun 2011 yang juga mengatur Tomira merupakan angin segar yang dapat menguntungkan bagi koperasi dan UMKM. Beberapa penelitian terdahulu di atas lebih memfokuskan terhadap implementasi dari kebijakan Toko Milik Rakyat (Tomira).

Berdasarkan penjelasan di atas, penelitian ini secara spesifik akan menganalisa proses formulasi kebijakan Toko Milik Rakyat (Tomira). Selain itu, pendekatan yang digunakan dalam analisa kebijakan pemerintah Kabupaten Kulon Progo terkait Toko Milik Rakyat (Tomira) yaitu menggunakan pendekatan analisis untuk kebijakan (Analysis for Policy) dengan fokus pada proses pembentukan kebijakan dan menggunakan model society based governance. Tujuannya ialah untuk mengetahui dan menganalisis proses formulasi kebijakan dengan melihat dengan sudut pandang society based governance. 


\section{METODE PENELITIAN}

Metode penelitian yang digunakan pada penelitian ini adalah metode studi kepustakaan yang kemudian di kolaborasikan dengan metode kualitatif. Metode kepustakaan ini merupakan suatu metode yang digunakan untuk mengumpulkan berbagai informasi dan data dari berbagai referensi seperti buku, jurnal, artikel, dan sebagainya. Menurut Danial dan Warsiah (2009) yang mengatakan bahwa studi kepustakaan merupakan metode penelitian yang dilakukan oleh peneliti dengan mengumpulkan sejumlah buku, majalah yang berkenaan dengan masalah dan tujuan penelitian. Metode ini dilakukan untuk mengumpulkan berbagai informasi yang relevan mengenai masalah yang akan diteliti.

Selain itu, metode kualitatif yang dijadikan sebagai metode yang melengkapi metode kepustakaan digunakan untuk meniliti terkait apa yang sebenarnya terjadi di dalam kondisi masyarakat atau kehidupan sosial dan bukan meneliti terkait apa yang seharusnya terjadi di kehidupan sosial. Menurut Craswell (2012), metode kualitatif adalah sebuah proses keingintahuan untuk memahami terkait apa saja permasalahan yang sedang terjadi di kehidupan masyarakat dan sosial dengan menggunakan penelitian yang mendalam, informasi dari banyak sudut pandang serta memahami kondisi natural yang sedang terjadi di masyarakat. Selain itu, pendekatan yang digunakan yaitu anlisis deskriptif terkait dengan kebijakan Pemerintah Kulon Progo tentang Toko Milik Rakyat (Tomira) Sehingga dari kedua metode ini penulis berharap akan adanya sebuah hasil konkrit terkait analisis proses pembentukan kebijakan Toko Milik Rakyat (Tomira).

\section{HASIL DAN DISKUSI}

Toko Milik Rakyat (Tomira) merupakan sebuah kebijakan Pemerintah Daerah Kabupaten Kulon Progo yang memiliki bentuk kemitraan antara Usaha Mikro Kecil dan Menengah (UMKM) dengan toko modern seperti Alfamart dan Indomaret yang ada di Kabupaten Kulon Progo. Pemerintah Daerah Kabupaten Kulon Progo berperan melindungi aktivitas ekonomi masyarakat, harus dapat meningkatkan kesejahteraan masyarakat, dan meningkatkan pembangunan ekonomi di Kabupaten Kulon Progo. 
Dalam bab ini, penulis akan menganalisis proses formulasi kebijakan dalam hal ini Toko Milik Rakyat (Tomira) di Kabupaten Kulon Progo berdasarkan alur kebijakan di bawah ini.

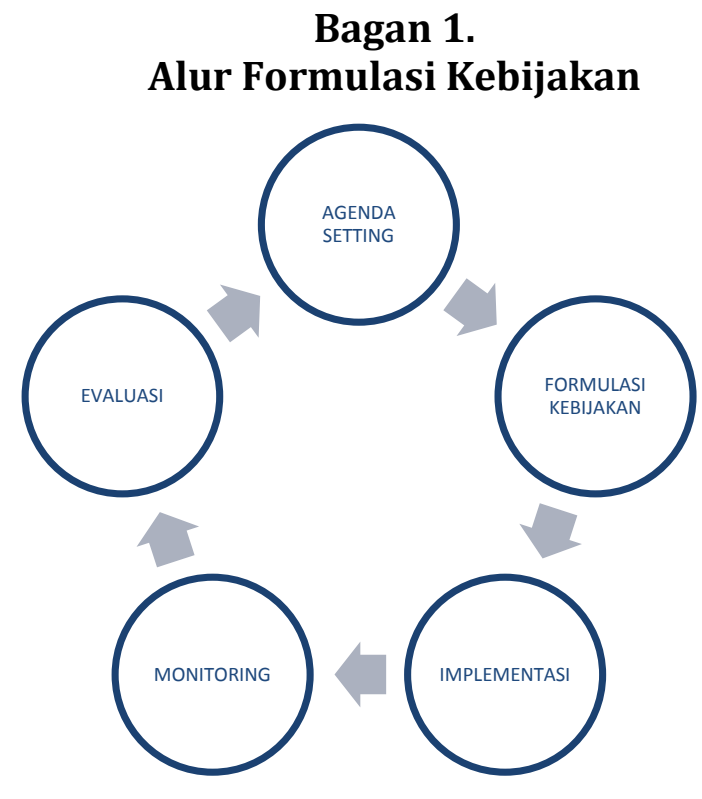

Sumber: Santoso (2010)

Kebijakan publik merupakan suatu prosess ketata pemerintahan dan administrasi pemenerintah yang menghasilkan keputusan pemerintah, dimana instansi yang terkait mempunyai kewenangan dan kekuasaan untuk mengarahkan masyarakat dan bertanggung jawab melayani kepentingan umum. Analisis formulasi kebijakan Toko Milik Rakyat (Tomira) yang merupakan produk pemerintah Kabupaten Kulon Progo dan dilandasi oleh Peraturan Daerah No. 11 tahun 2011 adalah suatu prosedur untuk menghasilkan informasi mengenai masalah yang terjadi di masyarakat berikut tindakan pencegahannya.

1. Pilihan Dilematis: Antara Market dan Society

Pembangunan ekonomi dilakukan untuk merespon datangnya pasar bebas, sehingga pembangunan ekonomi yang ada berbasis pasar. Hal ini kurang sesuai dengan sifat dasar masyarakat Indonesia yang bersifat komunal, berbasis komunitas. Dalam pasar, modal dan keuntungan adalah hal yang utama, sedangkan dalam komunitas kesejahteraan masyarakat, kebersamaan merupakan hal yang utama. 
Perekonomian nasional yang berasaskan demokrasi dan berbasis ekonomi pasar bebas yang adil harus diperkuat. Oleh karena itu, pemerintah perlu mengeluarkan sebuah kebijakan yang berlandaskan keadilan agar rakyat mendapatkan apa yang mereka butuhkan (equity) untuk meningkatkan kualitas hidup masyarakat, bukan sekedar eqality atau kesamaan perlakuan saja.

Pendirian toko modern di berbagai daerah perkotaan terutama di kota-kota metropolitan mendorong masyarakat berprilaku konsumtif. Hal ini lah yang merupakan salah satu alasan yang menyebabkan daya saing produk lokal suatu daerah akan kalah dengan produk dari toko-toko modern. Salah satunya terjadi di Kabupaten Kulon Progo, Provinsi Daerah Istimewa Yogyakarta. Masyarakat Kulon Progo cenderung menyukai toko modern seperti Alfamart dan Indomaret. Kondisi pasar tradisional di Kabupaten Kulon Progo semakin tergusur dengan adanya pendirian toko modern.

Hal tersebut diperparah dengan angka ketimpangan sosial ekonomi di Kulon Progo yang tergolong tinggi. Selain itu, berdasarkan data Badan Pusat Statistik Kabupaten Kulon Progo (2019) menunjukan bahwa angka kemiskinan di Kulon Progo pada tahun 2017 saja mencapai 20,03\% atau sekitar 84.170 orang.

Dapat dianalisis bahwa jika permasalahan pendirian toko modern di Kabupaten Kulon Progo tidak diatur oleh Pemerintah Daerah, maka dapat mengakibatkan meningkatnya tingkat kesenjangan baik sosial maupun kesenjangan ekonomi. Padahal Pancasila dan Undang-Undang Dasar Negara Republik Indonesia tahun 1945 mengamanatkan bahwa Negara Kesatuan Republik Indonesia mempunyai tanggung jawab untuk melindungi segenap bangsa Indonesia dan memajukan kesejahteraan umum dalam rangka mewujudkan keadilan sosial bagi seluruh rakyat Indonesia. Selain itu, UndangUndang No. 11 tahun 2009 tentang Kesejahteraan Sosial juga menjelaskan bahwa negara menjamin masyarakat untuk dapat memperoleh seluas-luasnya kesejahteraan baik secara sosial maupun ekonomi. 
Kesejahteraan yang diharapkan sebagai wujud kemerdekaan bukanlah kesejahteraan yang didapat oleh segelintir rakyat, akan tetapi kesejahteraan yang menyeluruh.

Maka dari itu pada proses agenda setting ini, pemerintah perlu memposisikan diri apakah kebijakan yang dibuat harus berorientasi pada pasar (market) atau masyarakat (society). Berdasarkan hasil analisis, penulis memetakan dua kemungkinan sebagai berikut.

Bagan 2.

Positioning Pemerintah Kabupaten Kulon Progo

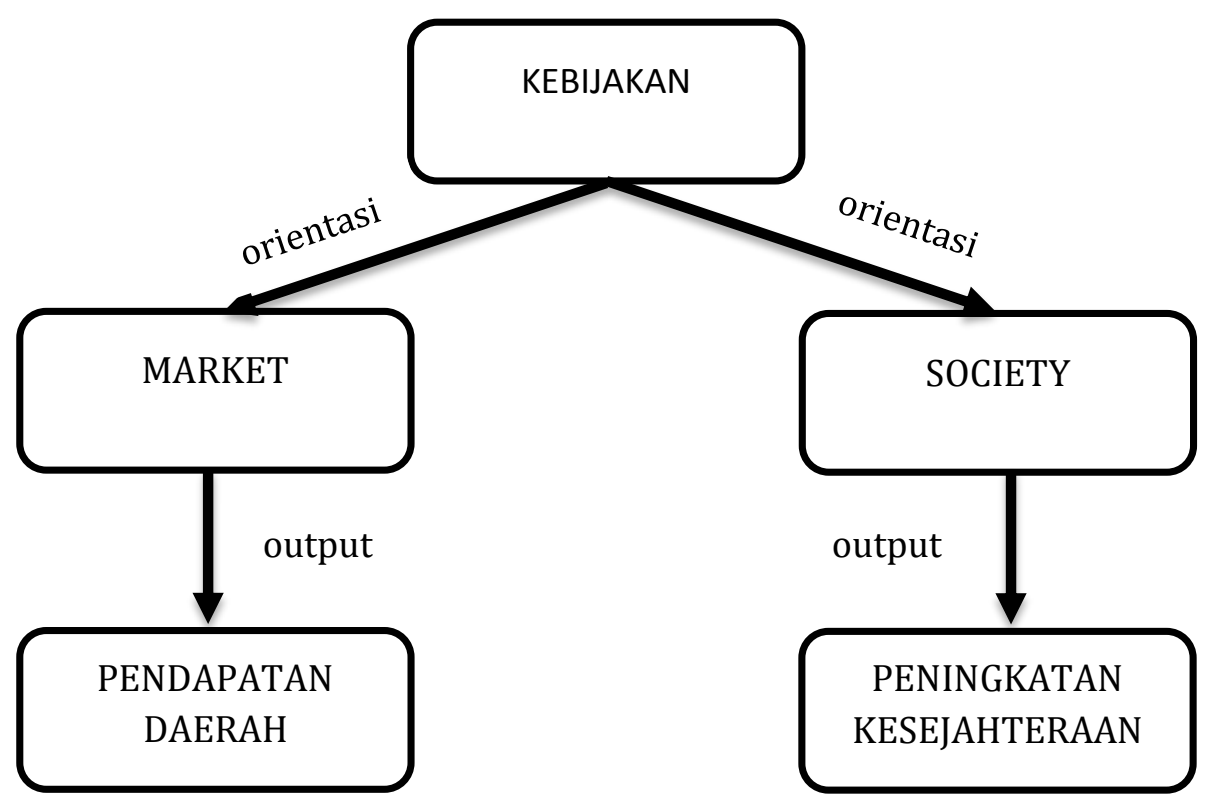

Sumber: diolah penulis

Tabel di atas menunjukan bahwa terdapat dua kemungkinan kecenderungan orientasi pemerintah dalam sebuah kebijakan untuk meningkatkan kesejahteraan masyarakat. Pertama, jika pemerintah memposisikan diri yang berorientasi kepada market atau pasar, maka output yang akan diterima oleh pemerintah salah satunya adalah meningkatnya pendapatan daerah melalui pajak. Namun, jika pemerintah terlalu berorientasi pada pasar, maka akan menciptakan masyarakat yang konsumtif. Selain itu, sejatinya kebijakan yang pemerintah buat harus dapat memberikan dampak positif langsung bagi masyarakat. 
Kedua, jika pemerintah memposisikan diri yang berorietnasi kepada society atau masyarakat, maka salah satu output yang akan diterima yaitu kesejahteraan masyarakat. Selain itu, masyarakat akan dapat berinovasi dan berkompetisi dengan pasar. Hal ini juga dapat merubah gaya hidup masyarakat yang awalnya konsumtif menjadi produktif.

Berdasarkan penjelasan di atas, penulis berharap kepada Pemerintah Daerah Kabupaten Kulon Progo agar dapat merumuskan sebuah kebijakan yang juga menguntungkan bagi masyarakat luas. Karena sejatinya kesejahteraan masyarakat dapat dicapai dengan kebijakan yang pro terhadap masyarakatnya. Salah satu kebijakan yang dapat diambil oleh Pemerintah Kabupaten Kulon Progo adalah kebijakan untuk menjamin kesejahteraan masyarakat melalui Toko Milik Rakyat (Tomira)

2. Mendefinisikan Masalah dan Positioning Kebijakan

Untuk mencapai tujuan kebijakan yang dalam hal ini adalah menciptakan kesejahteraan masyarakat melalui Toko Milik Rakyat (Tomira) perlu adanya berbagai tahapan yang harus di tempuh. Salah satu tahapan tersebut adalah tahapan formulasi kebijakan. Menurut Dunn (1995), formulasi kebijakan (policy formulation) adalah pengembangan sintesis terhadap alternatif-alternatif pemecahan masalah. Sedangkan menurut Winarno (2012) menyatakan bahwa masing-masing alternatif untuk di pilih sebagai kebijakan dalam rangka untuk memecahkan masalah. Secara sederhana, formulasi kebijakan ialah suatu proses pengambilan keputusan untuk menyelesaikan masalah yang terjadi di masyarakat. Yang dimaksud dengan pengambilan keputusan menurut Reason (1990) merupakan suatu hasil atau output dari suatu proses mental atau kognitif yang membawa pada pemilihan suatu jalur tindakan di antara beberapa alternatif yang tersedia. Setiap proses pengambilan keputusan selalu menghasilkan satu pilihan yang final.

Berdasarkan pada tahap agenda setting, penulis memetakan hanya ada 2 (dua) alternatif kebijakan yang ada. Pertama, kebijakan Toko Milik Rakyat 
(Tomira) yang berorientasi terhadap market atau pasar. Kedua, kebijakan Toko Milik Rakyat (Tomira) yang berorientasi terhadap masyarakat atau society.

Dalam tahap ini, untuk mencapai tujuan, penulis memparkan kerangka berfikir (logical framework). Pemaparan kerangka berfikir ini dapat memudahkan dalam memetakan berbagai hal yang menyangkut pada proses mencapai suatu kebijakan. Tahapan yang ditempuh yaitu membuat kajian-kajian terkait dengan kesejahteraan masyarakat dan menghimpun aktor-aktor yang memiliki pandangan yang sama. Sedangkan aktor-aktor yang terlibat yaitu pelaku ekonomi, Lembaga Swadaya Masyarakat (LSM) yang membahas tentang ekonomi, akademisi, pemerintah terkatit.

Bagan 3.

Kerangka Berfikir

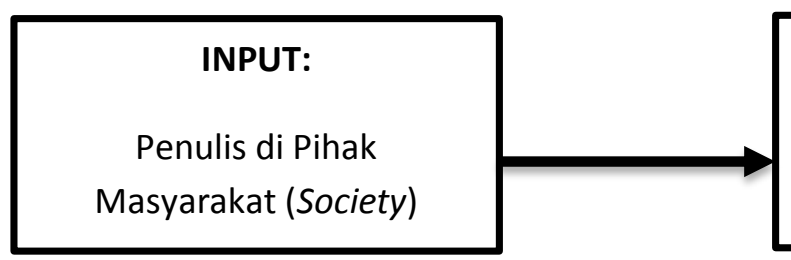

AKTIFITAS:

Kajian terkait kesejahteraan masyarakat

\begin{tabular}{|c|}
\hline OUTCOME: \\
Dengan keluarnya \\
peraturan daerah atau \\
peraturan bupati yang \\
memelindugi terkati Tomira \\
maka akan meningkatkan \\
kesejahteraan masyarakat \\
\hline
\end{tabular}

Sumber: diolah penulis

Berdasarkan pemaparan logical framework atau kerangka pikir diatas, maka formulasi kebijakan dapat dilakukan. Dalam tahap formulasi kebijakan ini, 
penulis menggunakan model mixed scanning. Inti dari model mixed scanning menjelaskan bahwa dalam suatu proses pengambilan keputusan, pengambil keputusan atau decission makers secara cepat mengumpulkan alternatifalternatif kebijakan. Setelah itu, alternatif-alternatif kebijakan yang sudah dikumpulkan lalu dianalisis dengan logika rasional untuk mendapatkanpilihan yang paling tepat dan sesuai dengan kebiasaan yang ada. (Agustino, 2016)

Selain itu, penulis menganalisis alternatif solusi dengan menggunakan teknik analisis SWOT (Strength, Weakness, Opportunity, Threat). Pertama Strength (Kekuatan). Dengan adanya otonomi daerah, Bupati atau pemerintah daerah memiliki kewenangan untuk membuat kebijakan untuk kesejahteraan rakyat. Kedua Weakness (Kelemahan). Kebijakan yang mengatur terkait dengan kesejahteraan masyarakat melalui Toko Milik Rakyat (Tomira) dapat digunakan sebagai strategi politik kepala daerah Kabupaten Kulon Progo, akan muncul konflik kepentingan antar aktor termasuk upaya lobbying pengusaha ke pemerintah itu mempengaruhi kebijakan, serta kurangnya kapasitas dan kapabilitas Sumber Daya Manusia (SDM) dalam mengelola program Toko Milik Rakyat (Tomira). Ketiga Opportunity (Peluang). Kebijakan yang mengatur terkait dengan kesejahteraan masyarakat melalui Toko Milik Rakyat (Tomira) menjadi peluang untuk meningkatkan kinerja baik pemerintah, menciptakan kepercayaan baik (trust) masyarakat terhadap pemerintah, meningkatkan produktifitas masyarakat, meningkatkan pendapatan masyarakat, meningkatkan keterampilan masyarakat, hingga menciptakan kesejahteraan masyarakat. Keempat Threat (Ancaman). Kebijakan yang mengatur terkait dengan kesejahteraan masyarakat melalui Toko Milik Rakyat (Tomira) akan dapat menghilangkan investor-investor yang ada di Kulon Progo terutama yang berinvestasi dalam pendirian toko modern.

Tabel 1.

Peta Analisis SWOT

\begin{tabular}{|l|l|lr|}
\hline & \multicolumn{2}{|c|}{ Strength } & \multicolumn{2}{c|}{ Weakness } \\
\hline Opportunity & $\begin{array}{l}\text { Kewenangan untuk } \\
\text { dimiliki yang }\end{array}$ & $\begin{array}{l}\text { Peluang } \\
\text { meningkatkan }\end{array}$ \\
\hline
\end{tabular}

Journal of Governance and Local Politics (JGLP)

ISSN (online): 2684-9992, Volume: 2, Nomor: 1, Mei 2020 


\begin{tabular}{|c|c|c|}
\hline & 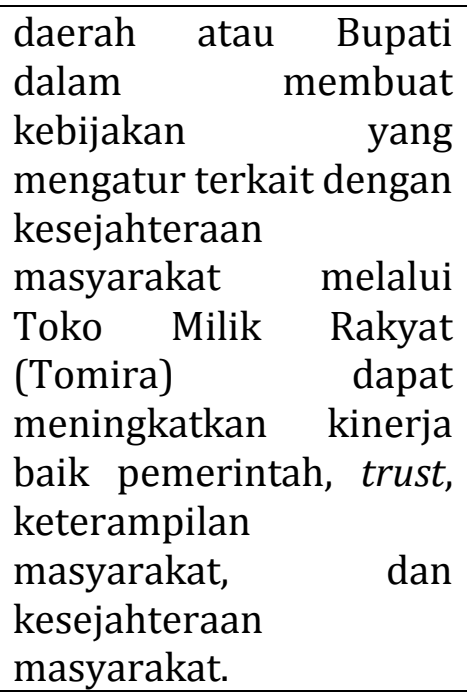 & $\begin{array}{l}\text { kesejahteraan } \\
\text { masyarakat dapat } \\
\text { terancam akibat konflik } \\
\text { kepentingan antar aktor. }\end{array}$ \\
\hline Threat & $\begin{array}{l}\text { Dengan kewenangan } \\
\text { pemerintah daerah atau } \\
\text { Bupati dalam membuat } \\
\text { kebijakan dan lobbying, } \\
\text { dapat menciptakan } \\
\text { solusi yaitu melakukan } \\
\text { kerjasama antar } \\
\text { pemerintah, masyarakat, } \\
\text { dan investor. }\end{array}$ & $\begin{array}{lr}\text { Konflik kepentingan } \\
\text { yang tidak terhindarkan } \\
\text { akan menjadi masalah } \\
\text { tambahan } \\
\text { mengancam kehilangan } \\
\text { investor. }\end{array}$ \\
\hline
\end{tabular}

Sumber: diolah penulis

Dari dua alternatif solusi yang telah dipaparkan dan tabel Swot di atas, penulis berpendapat bahwa alternatif kebijakan terkait dengan perlindungan dan peningkatan kesejahteraan masyarakat melalui Toko Milik Rakyat (Tomira) merupakan kebijakan terbaik yang banyak memiliki dampak yang positif dibanding alternatif kebijakan lain.

3. Implementasi Kebijakan Peningkatan Kesejahteraan melalui Toko Milik Rakyat (Tomira)

Dalam tahap analisis implementasi kebijakan ini dilakukan dengan cara implementasi untuk kebijakan. Menurut Grindle dalam Purwo Santoso (2010), implementasi kebijakan adalah upaya untuk mencapai tujuan kebijakan dalam formula kebijakan, sebagai policy statement kedalam policy outcome, yang muncul sebagai akibat dari aktivitas pemerintah. Selain itu, implementasi kebijakan merupakan tahap yang penting dalam analisis proses kebijakan. 
Dalam melakukan analisis implementasi kebijakan ini, penulis menggunakan model analisis yang dikemukakan oleh Grindle. Menurut Grindle dalam Leo Agustino (2016) menjelaskan bahwa terdapat dua variabel utama dalam implementasi kebijakan yaitu policy content dan policy context. Pada variabel policy conten, terdapat 6 faktor yang harus diamati dan dianalisis, yaitu:

a. Kepentingan-kepentingan yang mempengaruhi implementasi kebijakan (Interest affected)

Terdapat beberapa aktor dengan berbagai macam peran dan kepentingan di dalam proses pembuatan suatu kebijakkan publik. Dengan banyaknya aktor secara otomatis berbagai macam kepentingan di dalamnya. Dengan begitu akan memicu terjadinya perdebatan, resistensi hingga konflik. perdebatan, resistensi hingga konflik inilah yang ditakutkan akan menjadi hambatan dan berpotensi menimbulkan kegagalan dalam proses implementasi kebijakan.

Dalam proses implementasi kebijakan yang mengatur terkait dengan kesejahteraan masyarakat melalui Toko Milik Rakyat (Tomira) terdapat beberapa aktor yang ingin mengutarakan kepentingannya. Pertama, masyarakat selaku produsen Usaha Mikro Kecil dan Menengah (UMKM) akan terus mendukung dan mengawasi implementasi kebijakan karena hal tersebut dapat menguntungkan mereka seperti meningkatkan pendapatan pelaku usaha kecil. Selain itu sebagai pelaku usaha kecil, akan mendorong bagaimana caranya pemerintah untuk meningkatkan kuota produk lokal yang ada di Indomaret atau Alfamart, sehingga pelaku usaha kecil akan memiliki space dan meningkatkan kemungkinan pendapatan yang bertambah. Kedua, masyarakat sebagai konsumen, mereka akan mendukung implementasi kebijakan tersebut mengingat kualitas kebutuhan dasar mereka akan terjamin kualitas dan memiliki harga yang kompetitif. Ketiga, sebagai pengusaha mereka akan merasa sedikit dirugikan dengan penguasaan lahan ekonomi oleh masyarakat. Sehingga hal tersebut dapat menurunkan keuntungan mereka hingga akan 
mengakibatkan turunnya kemauan investasi khususnya toko modern di Kabupaten Kulon Progo. Selain itu, para pengusaha akan terus mempengarui kebijakan dan memngintervensi pemerintah agar membuat kebijakan yang menguntungkan mereka.

b. Manfaat dari implementasi kebijakan (Type of benefits)

Dalam implementasi kebijakan, manfaat yang diterima juga merupakan hal yang penting untuk di analisis, karena hal tersebut akan mempengaruhi pada proses implementasi kebijakan. Terdapat beberapa aktor yang otomatis mendapatkan manfaat dari kebijakan yang dikeluarkan oleh pemerintah. Dalam kasus implementasi kebijakan yang mengatur terkait dengan kesejahteraan masyarakat melalui Toko Milik Rakyat (Tomira) terdapat beberapa aktor yang mendapatkan manfaat yang menunjukan dampak positif yang dihasilkan oleh pengimplementasian kebijakan yang hendak di laksanakan. Pertama, manfaat yang diterima oleh masyarakat akibat implementasi kebijakan yang mengatur terkait dengan kesejahteraan masyarakat melalui Toko Milik Rakyat (Tomira) salah satunya adalah peningkatan pendapatan bagi pelaku usaha kecil. Kedua, berbeda dengan masyarakat, pengusaha juga tak luput dari implikasi manfaat positif yang dirasakan akibat implementasi kebijakan tersebut seperti menghindari konflik dengan masyarakat serta dapat mendukung pembangunan ekonomi yang inklusif. Maksudnya, pembangunan ekonomi yang menekankan pada pemerataan. Ketiga, selain masyarakat dan pengusaha, pemerintah juga mendapatkan maanfaat atas implemantasi kebijakan kesejahteraan ekonomi melalui Toko Milik Rakyat (Tomira) yaitu pemerintah dianggap berhasil dalam mengakomodir kepentingan, implementasi atas kebijakan tersebut dapat meningkatkan kepercayaan (trust) masyarakat terhadap kinerja pemerintah, serta dapat meningkatkan citra baik pemerintah daerah.

c. Derajat perubahan yang dicapai oleh kebijakan (Extent of change envision) 
Setiap kebijakan mempunyai target yang ingin dan hendak untuk dicapai. Dalam hal ini, penulis menganalisis perkiraan kemungkinankemungkinan perubahan yang akan terjadi dari sebuah kebijakan yang diimplementasikan. Namun dalam kasus ini, kebijakan yang mengatur terkait dengan kesejahteraan masyarakat melalui Toko Milik Rakyat (Tomira) seharusnya dapat berkontribusi besar terhadap kehidupan masyarakat. Perubahan yang diperkirakan akan terjadi oleh kebijakan tersebut adalah meningkatnya kesejahteraan masyarakat baik sosial maupun ekonomi, meningkatkan pertumbuhan ekonomi, menurunkan angka kemiskinan dan kesenjangan, serta dapat menurunkan jumlah angka pengangguran.

Beberapa hal tersebutlah yang akan menjadi derajat perubahan yang dicapai oleh kebijakan peningkatan kesejahteraan masyarakat melalui Toko Milik Rakyat (Tomira).

d. Letak pengambilan keputusan (Site of decission making)

Pengambilan keputusan dalam suatu kebijakan memiliki peran yang penting dalam pelaksanaan suatu kebijakan, maka perlu dijelaskan letak dari pengambilan keputusan dari suatu kebijakan yang diimplementasikan. Dalam kasus ini, kebijakan peningkatan kesejahteraan masyarakat melalui Toko Milik Rakyat (Tomira) berorientasi atau berposisi mendukung masyarakat (society based) karena kebijakan ini dirasa merupakan hal yang penting demi meningkatkan kesejahteraan masyrakat baik secara sosial maupun ekonomi. Selain itu, kebijakan ini juga merupakan ikhtiar pemerintah daerah Kabupaten Kulon Progo untuk menanggulangi atau mengurangi angka kemiskinan di Kabupaten Kulon Progo yang saat ini tergolong kedalam Kabupaten ke 2 dengan angka kemiskinan yang tinggi.

e. Pelaksana Program (Program Implementor)

Keberhasilan kebijakan publik bukakn hanya dinilai dari isinya saja yang membuat berhasil diterapkan, peran para pelaksana atau 
implementor program kebijakan publik juga berpengaruh dalam menentukan keberhasilan kebijakan. Winarno (2012) menjelaskan terdapat beberapa pelaksana program seperti badan birokrasi, lembaga legislatif, lembaga peradilan, kelompok-kelompok penekan (Pressure Group), organisasi-organisasi masyarakat.

Dalam kasus kebijakan ini, ketika pembentukan kebijakan telah sampai pada level penyetujuan pemerintah pusat, maka implementor program yang paling tepat adalah Dinas Koperasi dan UMKM Kabupaten Kulon Progo sebagai perwakilan Organisasi Perangkat Daerah (OPD), Kelompok Usaha Mikro Kecil dan Menengah (UMKM), investor atau pemilik Alfamart dan Indomaret, dan lain sebagainya.

f. Sumber daya yang digunakan (Resources Commited)

Dalam proses implementasi, sumberdaya (resources) juga dibutuhkan untuk mendukung agar implementasi berjalan dengan baik. Dalam kebijakan ini, penulis menganalisis beberapa sumber daya yang dibutuhkan, Pertama, proses implementasi menuntut adanya sumber daya manusia yang berkualitas sesuai dengan tugas pokok dan fungsi yang diisyaratkan oleh kebijakan. Namun, jika kapasitas dan kapabilitas sumber daya manusia nihil, maka tujuan baik kebijakan publik tidak akan tercapai. Kedua, selain sumber daya manusia, dalam proses implementasi kebijakan ini perlu didukung dengan sumber daya finansial seperti uang atau modal bagi masyarakat. Ketiga, jaringan, ini merupakan hal yang juga penting dalam implementasi kebijakan, alasannya yaitu agar aktor kebijakan atau implementator kebijakan dapat saling berkolaborasi dan berkoordinasi. Dalam kasus ini, penulis menganalisis jaringan sebagai berikut. 


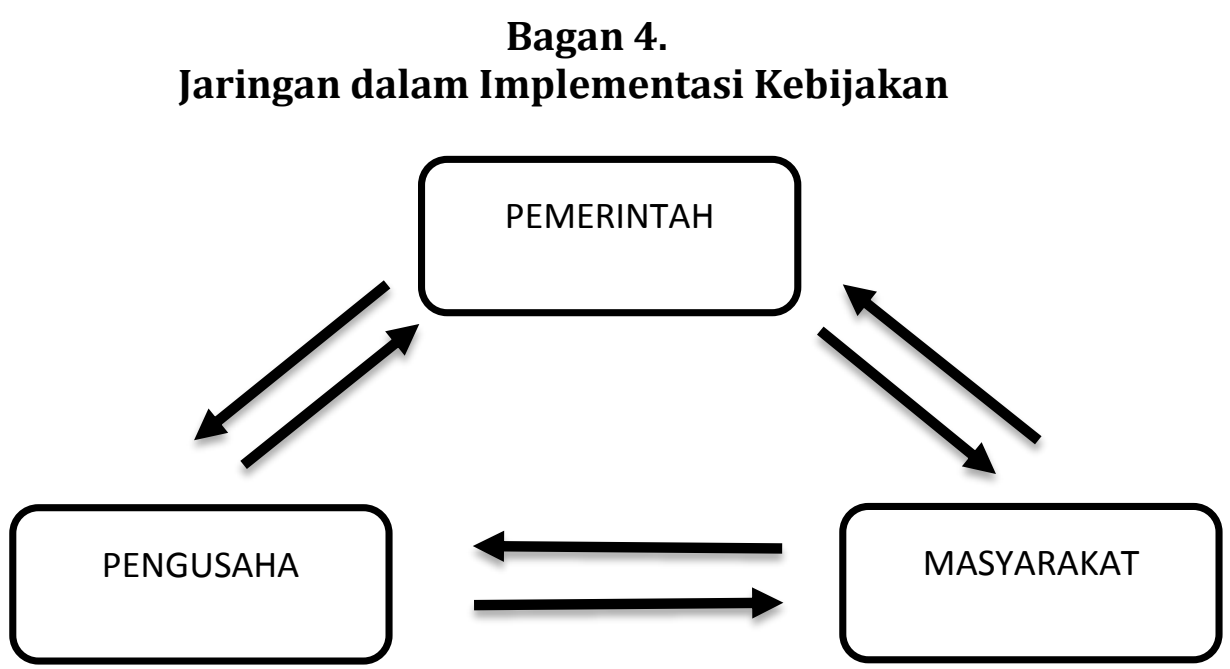

Sumber: diolah penulis

Berbagai elemen sumber daya diatas sangat penting hadir dalam sebuah kebijakan peningkatan kesejahteraan masyarakat melalui Toko Milik Rakyat (Tomira).

Selain 6 faktor yang harus diamati dan dianalisis pada variabel policy content, pada variabel policy context juga terdapat 3 faktor yang harus diamati dan dianalisis, yaitu:

a. Kekuasaan, kepentingan-kepentingan, dan strategi dari aktor yang terlibat (Power, interest, and strategy of actor involved)

Pada faktor pertama, kekuatan atau kekuasaan, kepentingan, dan strategi dari aktor yang terlibat perlu dipertimbangkan di dalam suatu kebijakan guna memperlancar implementasi suatu kebijakan. Bila hal ini tidak diperhitungkan secara matang, maka sangat besar kemungkinan kebijakan yang hendak di implementasikan akan jauh dari harapan bahkan hingga kegagalan. Dalam kasus ini, penulis memetakan kekuatan, kepentingan dan strategi aktor dalam kebijakan peningkatan kesejahteraan masyarakat melalui Toko Milik Rakyat (Tomira) yaitu

1. Pengusaha dan Lembaga Legislatif atau Pemerintah 
Relasi kepentingan yang akan terjadi yaitu pengusaha akan tetap berusaha melakukan negosiasi atau lobbying untuk mempengaruhi legislator agar kepentingan dapat pro terhadap market atau pasar.

\section{Bagan 5.}

Relasi Kepentingan antara Pengusaha dan Legislatif atau Pemerintah

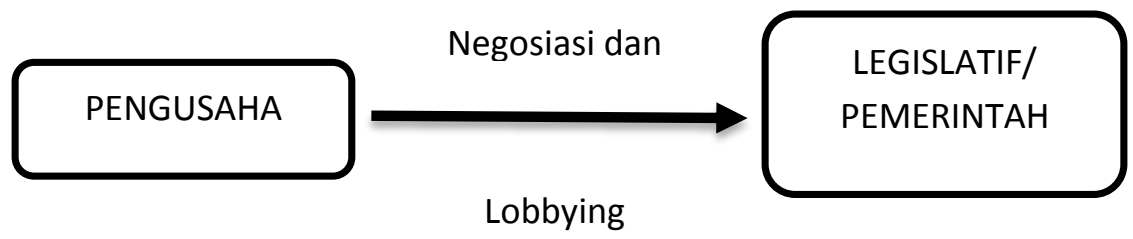

Sumber: diolah penulis

2. Pemerintah dan Pemerintah atau Lembaga Legislatif

Dalam melaksanakan kebijakan, pemerintah atau lembaga legislatif sebagai implementator akan bernegosiasi atau berkoordiasi dengan pengusaha untuk memberi ruang kepada masyarakat atau society.

\section{Bagan 6. \\ Relasi Kepentingan antara Legislatif atau Pemerintah dengan Pengusaha}

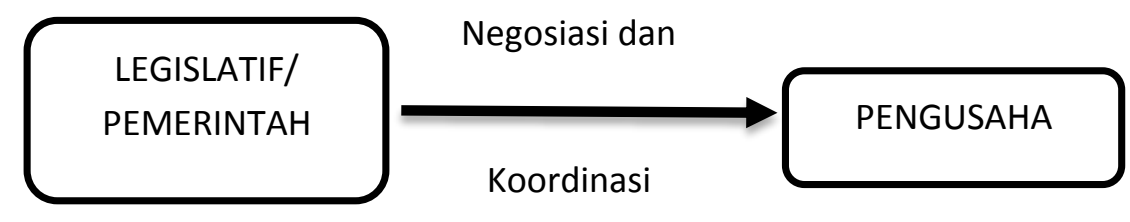

Sumber: diolah penulis

3. Selain relasi antar aktor, kepentingan yang hadir dari kebijakan peningkatan kesejahteraan masyarakat melalui Toko Milik Rakyat (Tomira) adalah mendongkrak popularitas kepala daerah sebagai implementor kebijakan. Kebijakan ini bisa menjadi strategi politik kepala daerah.

b. Karakteristik lembaga dan rezim yang berkuasa (Institution and regime characteristic) 
Lingkungan dimana suatu kebijakan diimplementasikan juga berpengaruh terhadap keberhasilan. Maka dalam bagian ini terdapat lembaga yang akan turut mempengaruhi suatu kebijakan. Dalam kasus ini, dengan adanya otonomi daerah, pemerintah daerah dapat membuat sebuah kebijakan secara cepat, efektif, dan efisien.

c. Tingkat kepatuhan dan respon dari pelaksana (Compliance and responsivness)

Hal yang juga penting dalam proses implementasi suatu kebijakan adalah kepatuhan dan respon dari pelaksana atau implementator. Dalam kasus ini menunjukan kepatuhan dan respon implementator. Pertama, Kelompok Usaha Mikro Kecil dan Menengah (UMKM) dalam menjalankan kebijakan harus di mobilisasi oleh pemerintah. Dengan alasan yaitu sumber daya manusia yang belum maksimal. Kedua, Pengusaha Toko Modern (Alfamart dan Indomaret) menganggap bahwa kebijakan terkait peningaktan kesejahteraan masyarakat melalui Toko Milik Rakyat (Tomira) yang dianggap sebagai penghambat pendapatan. Namun disisilain, ini merupakan keuntungan mereka untuk terhindar dari konflik sosial masyarakat. Dengan kata lain, ini merupakan hasil itung-itungan rasional ekonomi daripada tidak mendapatkan keuntungan sama sekali. Jadi dalam hal ini, pengusaha masih belum bisa menerima secara penuh kebijakan tersebut.

Selain beberapa aspek di atas, dalam implementasi kebijakan peningkatan kesejahteraan melalui Toko Milik Rakyat (Tomira) hal yang juga penting untuk di analisis ialah pola kepemilikan Tomira itu sendiri. Hal tersebut dapat dilihat dari alur kerjasama di bawah ini. 


\section{Gambar 1. \\ Alur Kerjasama antara UMKM dan Toko Modern (Alfamart dan Indomartl nada kasus Toko Milik Rakvat (Tomira)}
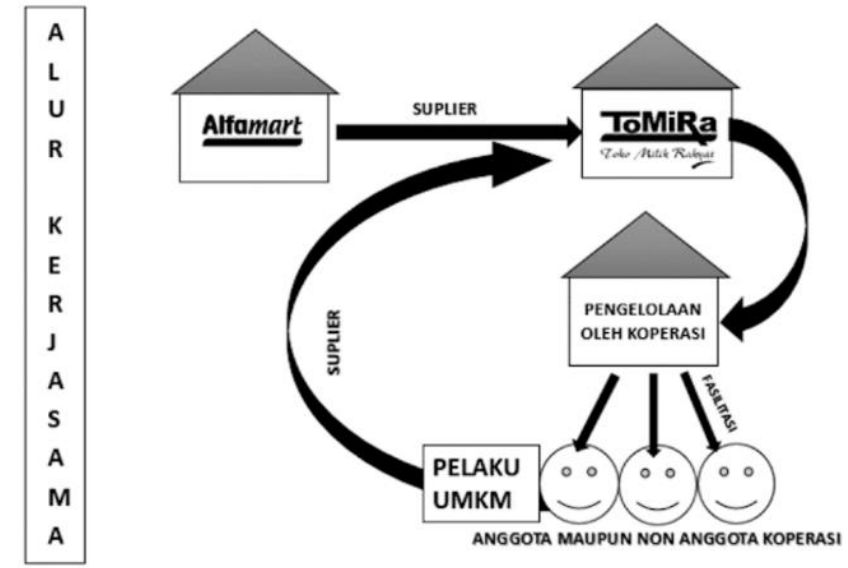

Sumber: Petugas Penyuluh Koperasi Lapangan Kabupaten Kulonprogo

Berdasarkan alur kerjasama diatas yang dimuat oleh Petugas Penyuluh Koperasi Lapangan Kabupaten Kulonprogo menunjukan bahwa peran masyarakat melalui UMKM yaitu; Pertama, masyarakat melalui UMKM berperan dalam pengelolaan Toko Milik Rakyat (Tomira); Kedua, selain Alfamart dan Indomaret, masyarakat melalui UMKM berperan sebagai suplier produk lokal yang tujuannya agar produk lokal bisa bersaing dengan produk-produk lain. Selain itu, tagline yang diangkat adalah "membela produk lokal dengan membeli produk lokal".

Selain sebagai suplier produk, pegawai yang bekerja di Tomira juga merupakan anggota dari Koperasi masyarakat Kabupaten Kulonprogo. Para pegawai koperasi yang bekerja di Tomira memiliki kewajiban yang sama pada saat mereka menjadi pegawai Alfamart dan Indomaret. Mereka pun mendapatkan perlakuan dan hak yang sama diberikan oleh koperasi. Pegawai Tomira juga dibayar setara dengan Upah Minimum Regional (UMR) Kabupaten Kulonprogo. Namun, terdapat syarat khusus untuk menjadi pegawai koperasi yang bertugas menjaga Tomira yaitu minimal tamatan SMA/ SMK/ sederajat. 
4. Monitoring Kebijakan Peningkatan Kesejahteraan melalui Toko Milik Rakyat (Tomira)

Tahap monitoring kebijakan merupakan sebuah tahap yang harus dilakukan dalam sebuah proses kebijakan publik dengan tujuan agar sebuah kebijakan yang telah dibuat dapat berjalan sesuai dengan rencananya. Menurut Hogwood and Gunn dalam Nugroho (2003), Monitoring kebijakan publik adalah suatu proses kegiatan pengawasan terhadap implementasi kebijakan untuk memperoleh informasi tentang seberapa jauh tujuan kebijakan itu tercapai.

Selain itu, menurut Dunn dalam Agustino (2016), monitoring memiliki empat fungsi Pertama, Ketaatan (Compliance) yang berarti bahwa tahap monitoring menentukan apakah tindakan implementator yang terlibat mengikuti dan sesuai dengan standar dan prosedur yang telah di tetapkan. Kedua, Pemeriksaan (Auditing), monitoring bertujuan untuk mengetahui apakah sumber dan layanan yang diperuntukan bagi pihak tertentu (target) telah tercapai. Ketiga, Laporan (Accounting), tahap monitoring dapat menghasilkan informasi yang membantu menghitung ada melaporkan hasil perubahan sosial dan masyarakat sebagai akibat implementasi kebijakan dalam periode waktu tertentu. Keempat, Penjelasan (Explanation), tahap implementasi berguna untuk menghasilkan informasi yang membantu menjelaskan akibat kebijakan dan mengetahui mengapa antara perencanaan dan implementasi tidak cocok.

Dalam kasus monitoring kebijakan peningkatan kesejahteraan masyarakat melalui Toko Milik Rakyat (Tomira) dapat dilakukan dengan cara Pertama, pemerintah sebagai implementator dapat melakukan monitoring dengan berbagai cara seperti melakukan pengawasan berkala terhadap pelaksanaan kebijakan, membuat kajian terkait kebijakan peningkatan kesejahteraan melalui Toko Milik Rakyat (Tomira) bilamana terjadi penyalahgunaan kebijakan, dan memastikan bahwa kebijakan harus dapat mengakomodir kepentingan seluruh aktor yang bersangkutan dengan kebijakan tersebut. Kedua, Usaha Mikro Kecil dan Menengah (UMKM) atau masyarakat dapat melakukan monitoring untuk menilai apakah kebijakan tersebut sesuai dengan rencana atau tidak. Monitoring 
tersebut dapat dilakukan dengan cara survey lapangan taerkait dengan jalannya program kebijakan peningkatan kesejahteraan melalui Toko Milik Rakyat (Tomira), menilai kinerja dari Sumber Daya Manusia (SDM) yang dimiliki, menganalisis lingkungan sebagai landasan untuk melakukan inovasi-inovasi produk yang akan dijual di Toko Milik Rakyat (Tomira), serta memastikan bagi hasil pendapatan dengan toko modern seperti Alfamart dan Indomaret secara jelas. Ketiga, selain pemerintah dan UMKM, pengusaha dalam hal ini pemilik toko modern (Alfamart atau Indomaret) yang juga sebagai implementator dapat melakukan monitoring dengan cara memastikan produk Usaha Mikro Kecil dan Menengah (UMKM) masyarakat masuk ke semua toko modern sesuai dengan kuotanya yaitu 20\% dan memastikan produk Usaha Mikro Kecil dan Menengah (UMKM) masyarakat memiliki kualitas yang terjamin dan berdaya jual.

5. Menilai Efektivitas dan Efisiensi Kebijakan

Tahap evaluasi kebijakan merupakan tahap yang penting dalam sebuah alur kebijakan. Pasalnya, pada tahap ini kita dapat melakukan penilaian apakah kebijakan yang telah dibuat dan diimplementasikan sesuai dengan rencana yang telah ditetapkan atau tidak. Evaluasi kebijakan juga berkaitan dengan tahap atau kegiatan monitoring kebijakan, karena tahap ecaluasi dapat menggunakan data yang telah didapatkan melalui tahap monitoring.

Menurut Lester \& Stewart dalam Agustino (2016) menjelaskan bahwa evaluasi kebijakan merupakan tahap yang berusaha untuk menilai konsekuensi kebijakan yang ditunjukkan oleh dampak-dampaknya dan menilai berhasil atau tidaknya suatu kebijakan berdasarkan pada kriteria dan standar yang telah dibuat. Selain itu, menurut Lester dan Stewart dalam Winarno (2012) tahap evaluasi kebijakan memiliki fungsi yaitu evaluasi kebijakan sebagai alat untuk mengukur kemajuan, menentukan konsekuensi-konsekuensi yang akan ditimbulkan, evaluasi kebijakan sebagai alat perencanaan, evaluasi kebijakan sebagai alat untuk perbaikan atau sebagai alat menilai keberhasilan atau kegagalan. 
Berdasarkan hasil analisis penulis, dalam tahap ini menilai bahwa pemerintah konsisten dalam menegakkan Peraturan Daerah dengan terus bertambahnya jumlah Tomira. Selain itu, Koperasi dan UMKM merasa diuntungkan dengan adanya Tomira tersebut. Namun, dalam kasus ini terdapat beberapa hal yang perlu dievaluasi. Pertama, kebijakan peningkatan kesejahteraan masyarakat melalui Toko Milik Rakyat (Tomira) lebih condong ke sisi politik sebagai strategi pemerintah daerah dan strategi peningkatan elektabilitas kepala daerah. Kedua, kurangnya kuota bagi Usaha Mikro Kecil dan Menengah (UMKM) untuk dapat memasarkan produknya di toko modern seperti Alfamart dan Indomaret. Ketiga, kurangnya informasi yang didapat oleh Usaha Mikro Kecil dan Menengah (UMKM) atau masyarakat terkait dengan kebijakan peningkatan kesejahteraan masyarakat melalui Toko Milik Rakyat (Tomira). Keempat, dalam hal manajemen toko, kemitraan model takeover atau akuisisi masih didominasi oleh peran PT karena keterbatasan kemampuan dan pengalaman dari koperasi. Kelima, kualitas dan kuantitas sumber daya manusia yang kurang, dan lain sebagainya.

Penulis merupakan pihak yang memposisikan diri berorientasi kepada masyarakat dimana penulis menekankan kepada pemerintah agar dapat membuat kebijakan baru dengan tujuan untuk memperjelas atau menspesifikan kebijakan yang telah ada dan dirasa memiliki kekurangan. Dampak positif dengan adanya kebijakan baru untuk memperjelas kebijakan lama agar masyrakat lebih memiliki kekuatan secara legal formal dan untuk menciptakan kesejahteraan masyarakat. Berbeda jika kebijakan pemerintah lebih berorientasi kepada pasar atau market. Maka sangat sulit untuk meningkatkan kesejahteraan masyarakat.

\section{KESIMPULAN}

Berdasarkan penjelasan di atas, kesimpulan dari analisis proses formulasi kebijakan Toko Milik Rakyat (Tomira) sebagai peningkatan kesejahteraan masyarakat Kabupaten Kulon Progo yaitu terdapat lima tahapan Pertama, tahap agenda setting. Kedua, tahap formulasi kebijakan. Ketiga, dalam analisis implementasi kebijakan, terdapat dua variabel utama dalam implementasi kebijakan yaitu policy content dan policy context. Keempat, monitoring kebijakan. Serta kelima, evaluasi kebijakan. Dalam kasus ini, terdapat beberapa Journal of Governance and Local Politics (JGLP) ISSN (online): 2684-9992, Volume: 2, Nomor: 1, Mei 2020 
hal yang perlu dievaluasi oleh Pemerintah Daerah Kabupaten Kulon Progo karena kebijakan tersebut dirasa masih kurang berorientasi terhadap masyarakat dan belum dapat menciptakan kesejahteraan yang seluas-luasnya.

Dari penjelasan diatas, penulis merekomendasikan kebijakan terkait peningkatan kesejahteraan melalui Toko Milik Rakyat (Tomira) yang dilandasi oleh Peraturan Daerah No. 11 tahun 2011 yaitu perlu dibuatnya kebijakan baru untuk memperjelas kebijakan lama yang memiliki beberapa kekurangan seperti kurangnya kuota yang didapat oleh masyarakat dalam menjual produknya, perlunya kejelasan terkait dengan bagi hasil antara masyarakat dan pengusaha toko modern, dan lain sebagainya; perlu adanya sosialisasi kepada masyarakat khususnya kepada Usaha Mikro Kecil dan Menengah (UMKM) lain yang ada di Kabupaten Kulonprogo terkait dengan kebijakan peningkatan kesejahteraan melalui Toko Milik Rakyat (Tomira); serta perlu adanya peningkatan Sumber Daya Manusia (SDM) atau pemberdayaan Usaha Mikro Kecil dan Menengah (UMKM).

\section{REFRENSI}

Agustino, L. (2016). Dasar-Dasar Kebijakan Publik. Bandung: Alfabeta.

Badan Pusat Statistik Kabupaten Kulon Progo. (2019). Penduduk Miskin dan Garis Kemiskinan.

Retrieved from https://kulonprogokab.bps.go.id/statictable/2015/03/10/15/penduduk-miskin-dangaris-kemiskinan-2003-2017.html

Danial, Endang, Nanan, W. (2009). Metode Penulisak Karya Ilmiah. Bandung: Laboratorium Pendidikan Kewarganegaraan.

Dunn, W. N. (1995). Analisa Kebijakan Publik. Yogyakarta: Hanindita Offset.

Harto, R. A. W. (2017). MAKNA SOSIAL TOKO MILIK RAKYAT (TOMIRA) Studi di Kabupaten Kulon Progo (Universitas Gadjah Mada). Retrieved from http://etd.repository.ugm.ac.id/index.php?mod=penelitian_detail\&sub=PenelitianDet ail\&act=view\&typ=html\&buku_id=116439\&obyek_id=4

Petugas Penyuluh Koperasi Lapangan Kabupaten Kulonprogo. (2014). Toko Modern Dimusuhi, Tomira Solusinya. Trom https://ppklkulonprogodiy.blogspot.com/2017/03/sinovik-2017-toko-moderen- 
dimusuhi.html

Rahmat, P. S. (2012). Penelitian Kualitatif. Jurnal Universitas Brawijaya, 2.

Reason, J. (1990). Human Error. New York: Cambridge University Press.

Riant, N. D. (2003). Kebijakan Publik, Formulasi, Implementasi, dan Evaluasi. Jakarta: PT Elex Media Komputindo.

Safitri, R. (2017). Tinjauan Etika Bisnis Islam Terhadap Praktik Toko Milik Rakyat (Tomira) di Kabupaten Kulon Progo (Universitas Islam Negeri Sunan Kalijaga Yogyakarta). Retrieved from http://digilib.uin-suka.ac.id/28802/1/13380064_BAB-I_IV-atauV_DAFTAR-PUSTAKA.pdf

Santoso, P. (2010). Analisis Kebijakan Publik. Yogyakarta: Research Centre for Politic and Government.

Setiyawati, Y. (2019). Implementasi Peraturan Bupati Kabupaten Kulon Progo Nomor 63 tahun 2010 tentang Pemberdayaan Koperasi dan UMKM (Studi UMKM Tomira di Kulon Progo) (Universitas Ahmad Dahlan). Retrieved from http://eprints.uad.ac.id/15282/

Sukmana, Y. (2014). Jumlah Pasar Modern di Indonesia Capai 23.000 Unit. Retrieved April 10, 2020, from Kompas website: https://ekonomi.kompas.com/read/2014/08/08/025100726/Jumlah.Pasar.Modern.d i.Indonesia.Capai.23.000.Unit

Susilo, E. G. B., \& Rijanta, R. (2017). KAJIAN IMPLEMENTASI “BELA-BELI KULON PROGO” (KASUS: AIR-KU, BATIK GEBLEK RENTENG, DAN TOMIRA). Jurnal Bumi Indonesia, 6. Retrieved from https://www.neliti.com/id/publications/228730/kajianimplementasi-bela-beli-kulon-progo-kasus-air-ku-batik-geblek-renteng-dan\#cite

Tambunan, T. H. (2010). Perekonomian Indonesia. Jakarta: Penerbit Ghalia.

Winarno, B. (2012). Kebijakan Publik Teori, Proses, dan Studi Kasus. Yogyakarta: CAPS.

Yasa, G. W. M. (2008). Penanggulangan Kemiskinan Berbasis Partisipasi Masyarakat di Provinsi Bali. Jurnal Ekonomi Dan Sosial INPUT, 88-89.

Zulkarnain. (2006). Kewuirausahaan (Strategi Pemberdayaan Usaha Kecil Menengah dan Penduduk Miskin). Yogyakarta: Adicita Karya Nusa. 